Article

\title{
Identifying Habitat Type Conservation Priorities under the Habitats Directive: Application to Two Italian Biogeographical Regions
}

\author{
Thomas Campagnaro * (1), Giovanni Trentanovi and Tommaso Sitzia \\ Department of Land, Environment, Agriculture and Forestry, Università degli Studi di Padova, 35020 Legnaro, \\ PD, Italy; giovanni.trentanovi@unipd.it (G.T.); tommaso.sitzia@unipd.it (T.S.) \\ * Correspondence: thomas.campagnaro@unipd.it; Tel.: +39-049-8272757
}

Received: 21 February 2018; Accepted: 30 March 2018; Published: 15 April 2018

check for updates

\begin{abstract}
The ongoing biodiversity crisis necessitates greater efforts to ensure the adequate conservation of critical habitat types. Even though the identification of protected areas is still required in Europe, conservation efforts are now focusing on management requirements for protected areas and habitat types. Establishing effective management approaches is important for the conservation of the natural and semi-natural habitat types that are identified under the Habitats Directive framework. In this study, we propose a methodology for determining priorities in the conservation management of habitat types based on readily available data. This method relies on four simple criteria to rank habitat types, which includes: conservation condition, biodiversity value, pressure factor, and the cover relevance of habitat types (indicating regional responsibility in terms of area covered). After ranking the habitat types based on the sum of the scores given to all of the criteria, the $25 \%$ top-ranking habitat types were prioritized. The pressure factors are analyzed using cluster analysis to better convey information regarding the management needs of groups of habitat types. This prioritization method was tested in habitat types occurring within the Italian Alpine and Continental biogeographical regions. From this analysis, forests, bogs and fens, and dry grasslands were identified as conservation priorities for the Alpine region; meanwhile, a wider variety of habitat types were identified for the Continental region. Important pressure factors were identified (e.g., roads and motorways) for these two biogeographical regions of Italy, which could be used to suggest specific conservation measures. The proposed approach represents a transparent and reliable method for outlining habitat-type priorities based on conservation, biodiversity, pressure, and cover factors, which can be applied to identifying conservation measures that can help achieve biodiversity targets.
\end{abstract}

Keywords: biodiversity conservation; conservation status; conservation management; prioritization; Natura 2000; biodiversity indicator

\section{Introduction}

The ongoing global biodiversity crisis (e.g., loss of species, habitat degradation) and lack of adequate funding to address the issue, highlights the need for a greater prioritization of conservation efforts, in order to ensure the protection of natural and semi-natural habitat types. An increasing number of political efforts are being undertaken worldwide in an attempt to stop the loss of biodiversity [1]. Within Europe, protecting biodiversity is viewed as a critical policy objective, and European Union (EU) member states have been at the forefront of many local, regional, and global conservation initiatives [2].

In 1992, the European Commission adopted the Habitats Directive (Directive 92/43/EEC), which is considered to be the most important European legislative accomplishment with respect 
to biodiversity conservation [3,4]. The Directive aims to protect European natural and semi-natural habitat types, flora, and wildlife, with a specific focus given to habitat types and species that are defined as being of "Community interest". The Habitats Directive defines habitat types as "terrestrial or aquatic areas distinguished by geographic, abiotic, and biotic features, whether entirely natural or semi-natural", and are commonly described through phytosociological units, with some smaller number being described as landscape units [5]. The habitat types and species of "Community interest" for which protection and restoration measures are needed are listed in Annex I, II, IV, and V (see the Habitats Directive for specific definitions). To safeguard these species and habitat types, the Directive calls for the establishment of protected sites that form the Natura 2000 network, which is one of the largest conservation areas worldwide [6,7]. Article 17 of the Directive requires member states to periodically report (i.e., every six years) on the conservation status of habitat types and species and on the conservation measures undertaken in their territory. These data must be reported for each of the nine terrestrial and five marine biogeographical regions, following a standard methodology and format [8].

According to the latest EU composite report based on these national reports, $30 \%$ of habitat types and $18 \%$ of species assessments have a bad conservation status at the EU level [9]. In the most recent assessment, changes were made in the information collection method, which resulted in the availability of more accurate data [9]. Despite this improvement, several important flaws in the assessments have been identified with respect to information on habitat types and species. These include the difficulty in acquiring accurate information [10,11], deficient classifications [12], and the use of non-objective methods (e.g., expert opinion), which makes comparisons between countries and reporting periods difficult $[13,14]$. However, the use of additional methods (e.g., models) in addition to field data may help improve the accuracy and usefulness of these assessments [15], and countries are improving their efforts towards the direct monitoring of habitat types and species [16,17]. Indeed, much progress is still needed both for species and habitat types in terms of the accuracy and availability of updated data. Furthermore, target 1 of the EU 2020 Biodiversity Strategy requires that 100\% or more of habitat-type assessments and $50 \%$ or more of species assessments be favorable or improving when compared with the composite report for the 2001-2006 period [18]. Therefore, when comparing these objectives with the results of the latest EU composite report, there is still a great need for improvement in their conservation status [9].

Conservation problems and negative trends should be addressed by: identifying the main pressures that require management measures, prioritizing the issues to be addressed, and effectively planning the measures that will be taken. A number of studies conducted in the EU have investigated the Natura 2000 network to identify the gaps, effectiveness, and representativeness of current conservation efforts at multiple spatial scales. These studies have underlined a number of priorities, both in terms of the taxa and geographic areas that need to be better addressed [4,19-23]. Furthermore, many different approaches for species conservation prioritization have been proposed [24-27]. However, relatively little focus has been given to the habitat types, their pressure factors, and the conservation measures that are required to achieve or maintain good conservation status.

Habitat types are usually ranked by the biodiversity value of their plant communities $[28,29]$ and the national responsibility for each habitat type [14,30]. For example, Bacchetta et al. [31] ranked habitat types based on their endemic plant richness and related priority index value. Attention has frequently been focused on assessing habitat-type conservation priorities at the scale of the Natura 2000 sites and network levels [32-34]. For example, Mikkonen and Moilanen [35] used the Zonation framework and software, which is a spatially explicit modeling tool, to identify areas of conservation priority within the Natura 2000 network. Other approaches have considered multiple criteria, used scoring methods, and applied specific decision rules to indicate conservation priorities and focused on habitat vulnerability $[25,28,36]$. These approaches focus on identifying the habitat types or species that are most in need of conservation; other approaches have focused on what conservation benefits could be most quickly achieved at the biogeographical level i.e., the "low-hanging fruit" approach [37]. 
Most of these approaches focus on prioritizing conservation among habitat types, but lack a direct link to the pressures influencing the conservation status of habitat types, and possible conservation measures [38,39]. A large variety of human activities occur in Natura 2000 sites, which may introduce various pressures to different habitat types [40]. Furthermore, novel approaches should consider data availability together with the assessment requirements of the Habitats Directive, while taking into account the spatial scale that would be appropriate for the regulatory framework. Under the Habitats Directive, several spatial scales are important for administrative and management reasons, including: the EU, biogeographical regions, EU member states, Natura 2000 sites, and cross-cutting combinations of scale (e.g., biogeographical regions of an EU member state). Despite this, identifying priorities across administrative scales is difficult [41]. In the context of the Habitats Directive, future actions should prioritize conservation measures to attain and maintain the favorable conservation status of habitat types and species [42]. Indeed, there is a demand for scientific support to identify conservation priorities and feasible management options [43-46].

The objectives of this study are to develop a simple method for prioritizing the conservation of natural and semi-natural habitat types, and help suggest appropriate conservation management measures. The proposed approach ranks habitat types based on their combined evaluation according to four criteria: (i) conservation condition; (ii) biodiversity value; (iii) pressure factor; and (iv) cover relevance (indicating regional responsibility in terms of area covered by the habitat type). Scores are assigned to the parameters of each criteria by capitalizing on data available from assessments under Article 17 of the Habitats Directive. After selecting the top 25\% ranked habitat types, an in-depth analysis was used to determine the most dominant and cross-cutting pressure factors in order to identify which specific conservation measures to apply. The proposed methodology was then tested in the Alpine and Continental biogeographical regions of Italy in order to identify the conservation management priorities for the habitat types of these areas.

\section{Materials and Methods}

\subsection{Study Area}

The method was tested for the habitat types occurring within the Alpine and Continental biogeographical regions of Italy (Figure 1). The Alpine biogeographical region covers the Italian Alpine range and two relatively small areas in central Italy within the Apennines (i.e., Maiella massif and Gran Sasso mountain). This biogeographical region covers around $51,000 \mathrm{~km}^{2}$ in Italy. The last national report [47] assessed 76 habitat types, 47 plant species, and 116 animal species listed in Annex I, II, IV, and V. The most represented habitat-type category was forests (26), followed by grasslands (13), freshwater habitats (12), and rocks and screes (9).

The Continental biogeographical region covers the Po plain and parts of the Adriatic coast. This biogeographical region covers around $88,000 \mathrm{~km}^{2}$. The last national report assessed 83 habitat types, 38 plant species, and 124 animal species listed in Annex I, II, IV, and V [47]. The most represented habitat-type category was forests (21), followed by grasslands (13), freshwater habitats (12), and dunes (9). 


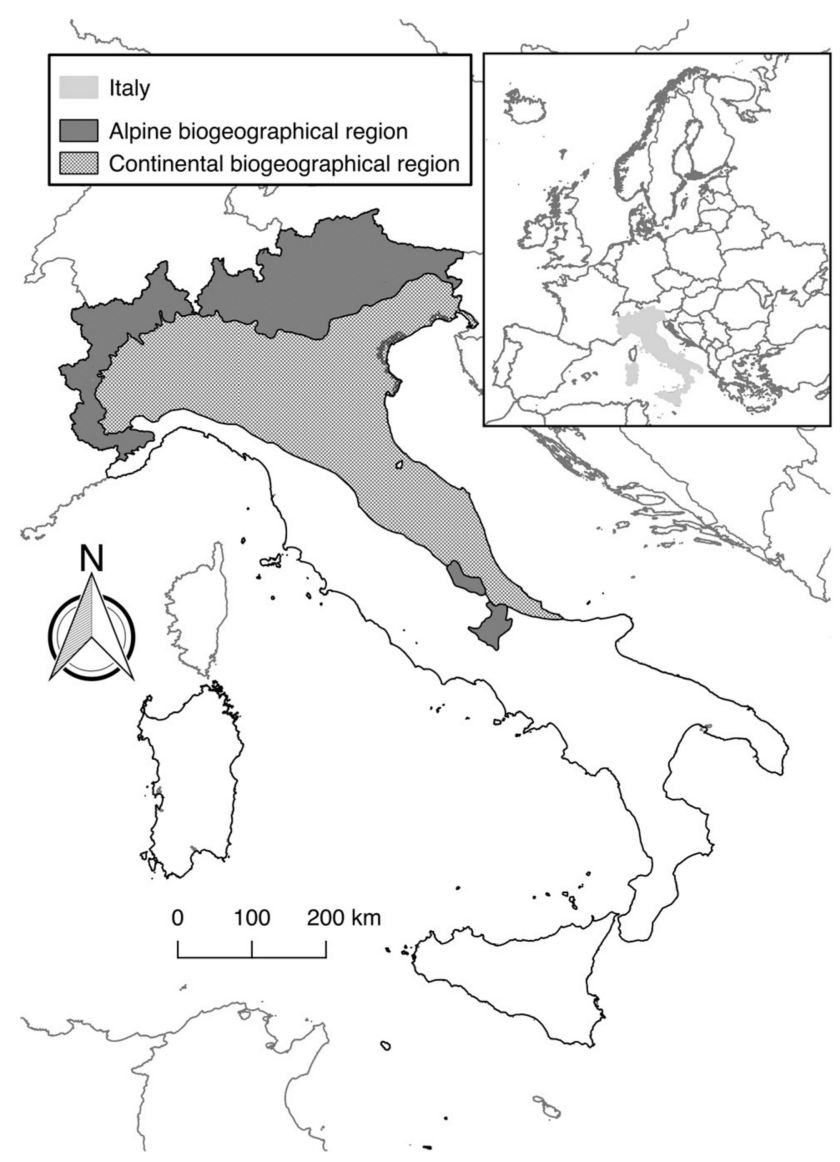

Figure 1. The Alpine and Continental biogeographical regions of Italy used to test the proposed method.

\subsection{Methodological Framework}

Our approach was based on a multi-criteria decision framework, which has been widely adopted to help solve environmental planning and management issues [48]. Multi-criteria analysis enables the quantification and scoring of quantitative and qualitative criteria and parameters to efficiently achieve transparent results, such as ranking different decision options [49]. After selecting criteria and parameters, the assessment of each criterion was derived as the sum of assigned scores to the values that were recorded to each parameter. Scores were then standardized to a given value range to enable comparisons. Finally, ranking was made possible by summing the total scores assigned to the different criteria.

The method that was applied to identify habitat-type conservation priorities was based on a set of four criteria. These criteria were: (i) conservation condition; (ii) biodiversity value; (iii) pressure factor; and (iv) cover relevance (Figure 2 and Table 1). All of these criteria are related to specific parameters derived from the official data reported to the European Commission by Italy; this data is presented and summarized in Genovesi et al. [47]. Member States' reports under Article 17 for all of the species and habitat types can be found at http:/ / bd.eionet.europa.eu/activities/Reporting/Article_17. This data is the most comprehensive currently available for habitats of "Community interest". 
Table 1. Summary of the selected criteria with information on their total ranges prior to rescaling, parameters (their values and related scores), reference to studies adopting similar approaches, and applied equations.

\begin{tabular}{|c|c|c|c|c|c|c|c|}
\hline \multirow[b]{2}{*}{ Criteria } & \multirow[b]{2}{*}{ Parameters } & \multirow[b]{2}{*}{ Values } & \multirow[b]{2}{*}{ Scores } & \multicolumn{2}{|c|}{ Possible Range before Rescaling } & \multirow{2}{*}{$\begin{array}{l}\text { Studies Adopting } \\
\text { Similar Criteria } \\
\text { or Parameters }\end{array}$} & \multirow[b]{2}{*}{ Equation } \\
\hline & & & & Alpine & Continental & & \\
\hline $\begin{array}{l}\text { Conservation } \\
\text { condition }\end{array}$ & $\begin{array}{c}\text { Range }(\mathrm{R}) \\
\text { Area }(\mathrm{A}) \\
\text { Structure and functions }(\mathrm{S}) \\
\text { Future prospects }(\mathrm{F}) \\
\end{array}$ & $\begin{array}{c}\text { Favorable } \\
\text { Unknown } \\
\text { Inadequate } \\
\text { Bad }\end{array}$ & $\begin{array}{c}0 \\
0.33 \\
0.66 \\
1\end{array}$ & $0-4$ & $0-4$ & {$[25,35,37]$} & ${ }^{1} C C_{i}=R_{i}+A_{i}+S_{i}+F_{i}(1)$ \\
\hline \multirow{7}{*}{$\begin{array}{l}\text { Biodiversity } \\
\text { value }\end{array}$} & \multirow{2}{*}{ Priority $(\mathrm{P})$} & No & 0 & \multirow{7}{*}{$0-\infty$} & \multirow{7}{*}{$0-\infty$} & \multirow{7}{*}[28,35,50,51]{} & \multirow{7}{*}{${ }^{2} C V_{i}=P_{i}+\sum H D_{i j}+\sum R l_{i j}+\sum E_{i j},(2)$} \\
\hline & & Yes & 1 & & & & \\
\hline & $\begin{array}{l}\text { Species of the Habitats } \\
\text { Directive Annexes (HD) }\end{array}$ & $\begin{array}{c}\text { Annex V } \\
\text { Annex IV } \\
\text { Annex II } \\
\text { Priority Annex II }\end{array}$ & $\begin{array}{c}0.25 \\
0.5 \\
0.75 \\
1\end{array}$ & & & & \\
\hline & \multirow[t]{2}{*}{ Red list species (Rl) } & $\begin{array}{l}\text { Least Concern } \\
\text { Near Threatened } \\
\text { Vulnerable } \\
\text { Endangered }\end{array}$ & $\begin{array}{l}0.1 \\
0.2 \\
0.3 \\
0.4\end{array}$ & & & & \\
\hline & & Critically Endangered & 0.5 & & & & \\
\hline & \multirow{2}{*}{ Endemic species (E) } & No & 0 & & & & \\
\hline & & Yes & 0.5 & & & & \\
\hline Pressure factor & $\begin{array}{l}\text { Pressures }(p) \\
\text { Threats }(t)\end{array}$ & $\begin{array}{l}\text { Low } \\
\text { Medium } \\
\text { High }\end{array}$ & $\begin{array}{c}0.33 \\
0.66 \\
1\end{array}$ & $0-\infty$ & $0-\infty$ & {$[33,52]$} & ${ }^{3} P F_{i}=\sum_{p}\left(P_{p i}\right)+\sum_{t}\left(T_{t i}\right)$ \\
\hline Cover relevance & Cover relevance (CR) & Area proportion & $0-1$ & $0-1$ & $0-1$ & {$[25,30,53,54]$} & ${ }^{4} C R_{i}=A_{C i} / A_{T i},(4)$ \\
\hline
\end{tabular}




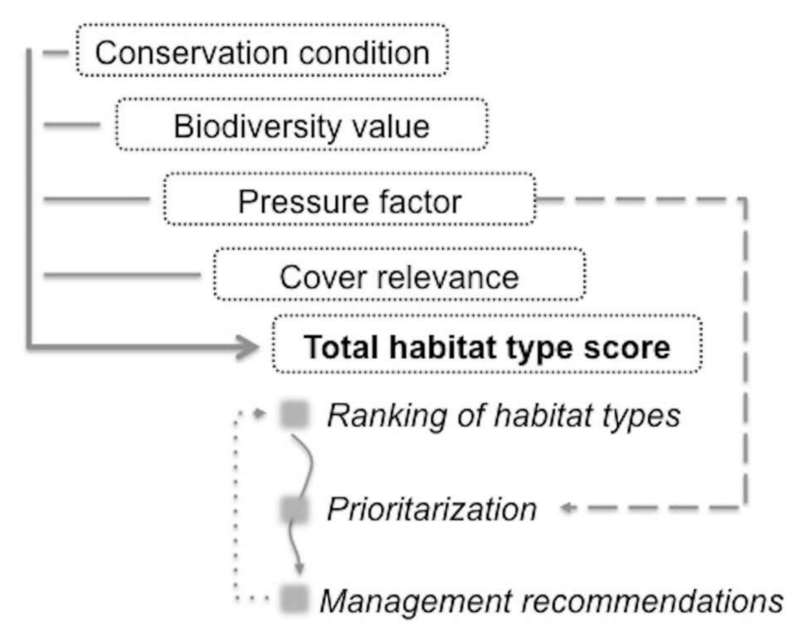

Figure 2. Stages for identifying habitat-type conservation priorities.

The value of each criterion was standardized to enable comparisons, with the value of each criteria scaled by the highest value assigned by Cain and Harrison (1958) as cited in [55], with the result of each criterion being rescaled from 0 to 1 . This procedure does not alter the relative distance among the values recorded for the criteria, and the value ranges are then comparable across criteria [33]. The current method assigned equal weight to each criterion and parameter; therefore, there is no hierarchy between criteria, thus representing a neutral perspective. As an alternative, different weights could be assigned to reflect an a priori assumption of the relative importance of the different criteria.

Varying numbers of parameters were used for the different criteria, depending on available information and their significance for habitat-type prioritization. This variability in the number of parameters between criteria is commonly observed in multi-criteria analysis applications [33]. Each parameter was valued through a scoring approach, as detailed in Table 1, which follows an approach adopted in other studies [56]. These scores were equally spaced for each parameter in order to represent an equal relationship between the values, and higher scores represented a higher conservation priority for that specific parameter.

The final score of the criteria was derived from the scalar value of the summed values assigned to the parameters. These criteria were then used to detect priorities by identifying the habitat types "most in need", which were those habitat types for which prompt management action is most important, as determined by the sum of linear combinations.

\subsubsection{Conservation Condition}

Conservation condition is commonly used to prioritize species and habitat conservation $[25,35]$. EU member states are required to report on the conservation status of the habitat types that are listed in Annex I. The overall conservation status of one habitat type in a biogeographical region derives from separate evaluations of four parameters: range, area, structure and functions, and future prospects [8]. In this assessment, each parameter was assigned one of four classes: FV = "Favourable", $\mathrm{U} 1=$ "Unfavourable/Inadequate", U2 = "Unfavourable/Bad", and XX = "Unknown". We assigned a lower score to "Unknown" values, given that a lack of data may represent the need for more monitoring, rather than a biodiversity priority requiring management measures. However, such an approach could have drawbacks in areas that are both data scarce and at conservation risk.

\subsubsection{Biodiversity Value}

Habitats are indicators of biodiversity [57]; therefore, when prioritizing conservation efforts, it is important to underline the significance of different habitat types in terms of biodiversity conservation values. Habitat types (and species) listed in the Habitats Directive are differentiated between priority 
(identified with an asterisk) and non-priority. Priority habitat types are those considered to have added biodiversity value, which according to Article 1 are "in danger of disappearance" and are considered to be of "particular responsibility" for EU member states. However, this definition of the most vulnerable habitat types [25] does not always match with vulnerability at the regional and national level. For example, habitat type $4070^{*}$ bushes with Pinus mugo and Rhododendron hirsutum (Mugo-Rhododendretum hirsuti) is identified as a priority by the Habitats Directive, but usually not at the alpine level, due to its wide regional distribution. In this study, we screened the list of typical species reported for the single biogeographical regions of Italy to identify species listed in Annex II, IV, and V of the Habitats Directive and in the national Red List.

\subsubsection{Pressure Factor}

Pressure factors are defined here as external factors that act with a detrimental effect on the habitat type. To derive the pressure factor criterion, we considered the list of pressures and threats that can affect the habitat types that are used for reporting under Article 17. This list is derived from a combination of different lists reporting specific actions that can be detrimental [58]. While pressures refer to factors currently affecting the habitat type (i.e., during the reporting period), threats are factors that are expected to affect the habitat type in the near future [8]. For each identified pressure, whether current or future, the assessment assigned three possible categorical values, taking into consideration the intensity and area of influence.

\subsubsection{Cover Relevance}

The cover relevance criterion is related to the geographical distribution of the different habitat types; it derives from the area covered by the habitat type. This criterion is similar to that of the regional [55] and national [14] responsibility approaches. Cover relevance indicates how much area is covered by the habitat type in that country's biogeographical region compared to the total area reported for the same biogeographical region. Therefore, higher scores indicate a higher responsibility for the member state toward the conservation of the habitat type in the biogeographical region.

\subsubsection{Total Habitat Type Score}

After the schematic computation of each criterion and the standardization of their value (i.e., between $0-1$ ), the total score for habitat types was calculated. This calculation was made using the sum of the scores of the four criteria for each habitat type. Therefore, the final value varied between 0 and 4, with higher scores indicating a higher conservation priority. Following this, each habitat type was ranked based on this value. Making rankings based on the sum of scores for a set of criteria is a commonly applied method for identifying priorities [25].

To examine the impact of ranking habitat types based on a unique set of scores for the different parameters, a sensitivity analysis was performed by using two alternative score schemes. We recalculated total scores for the habitat types using a set of scores representing two alternatives: one exacerbating the differences between values, and one giving a stronger importance to unknown information and to species of conservation concern. Recalculating scoring outcomes is important to make decision makers aware of the impact that assumptions have on this prioritization approach.

\subsubsection{Habitat Type and Pressure Prioritization}

To identify pressures that can help determine management actions for habitat types of conservation priority, the top-ranking habitat types ( $25 \%$ of the total) were selected. The selection of the top $25 \%$ is a subjective decision, and could vary based on political, social, and economic objectives or constraints.

However, it is also important to consider that a single pressure factor can impact several habitat types; therefore, tackling a single pressure can have beneficial effects on several habitat types. A cluster analysis was also performed to assess whether there were groups of habitat types subjected to similar 
pressures, which could allow the formulation of conservation measures that would have benefits across multiple habitat types [54]. This analysis was made using ordinal data that corresponded to the different degrees of pressure and threats (i.e., the raw values assigned to pressures and threats according to scores as in Table 1 without their scaling). The scores given to each pressure and threat for each habitat type were then summed to a unique value representing all of the pressure factors for a single habitat type. All of the analyses were performed using the R statistical program [59]. We used the city-block distances by applying the "Manhattan" metric, where the distances are the sum of the absolute differences. The use of city-block distance is the most appropriate approach when variables are on an ordinal scale [60]. The data was then analyzed as an agglomerative hierarchical clustering by using Ward's clustering method. To assess which pressure factors should be prioritized, we identified the pressure factors that were shared by groups of habitat types. First, we identified the most common pressure factors (i.e., those that affected more than $50 \%$ of the habitat types), and then we identified groups from the cluster analysis that adequately represented these habitat types. To investigate which pressure factors defined these groups, we applied the indicator value analysis [61]. We used the "multipatt" function, which evaluated the association between pressure patterns and combinations of groups of habitat types, and the "indicspecies" package for the application of the indicator value method (using the IndVal.g index) in R [62]. A Monte Carlo test with 999 randomizations was used to verify statistical significance, and group combinations were considered.

\section{Results}

The method developed in this study was used to rank the habitat types in the Alpine and Continental biogeographical regions of Italy, with the top 25\% ranked habitat types provided in Tables 2 and 3 (see Supplementary Material Tables S2 and S3 for the full list). In the Alpine biogeographical regions, the 19 top ranked habitat types were forest (10), bog and fen (5), and grassland (4). In the Continental biogeographical region, the top 21 ranked habitat types covered a wider variety of habitats, including: dunes (5), coastal (5), forest (4), grassland (3), freshwater (2), and fen (2).

Table 2. Habitat types of the Italian Alpine biogeographical region ranked with the proposed method ( ${ }^{*}$ highlight priority habitat types sensu Habitats Directive).

\begin{tabular}{|c|c|c|c|}
\hline Rank & Habitat Type Code & Habitat Type Name & Priority Score \\
\hline 1 & 6240 & * Sub-Pannonic steppic grasslands & 2.70 \\
\hline 2 & 7230 & Alkaline fens & 2.47 \\
\hline 3 & 91H0 & * Pannonian woods with Quercus pubescens & 2.41 \\
\hline 4 & $62 \mathrm{~A} 0$ & Eastern sub-Mediterranean dry grasslands (Scorzoneratalia villosae) & 2.39 \\
\hline 5 & 91F0 & $\begin{array}{l}\text { Riparian mixed forests of Quercus robur, Ulmus laevis and Ulmus minor, } \\
\text { Fraxinus excelsior or Fraxinus angustifolia, along the great rivers (Ulmenion minoris) }\end{array}$ & 2.32 \\
\hline 6 & 91E0 & $\begin{array}{l}\text { *Alluvial forests with Alnus glutinosa and Fraxinus excelsior (Alno-Padion, } \\
\text { Alnion incanae, Salicion albae) }\end{array}$ & 2.32 \\
\hline 7 & 6210 & $\begin{array}{l}\text { Semi-natural dry grasslands and scrubland facies on calcareous substrates } \\
\text { (Festuco-Brometalia) }\left({ }^{*} \text { important orchid sites) }\right.\end{array}$ & 2.31 \\
\hline 8 & 7110 & * Active raised bogs & 2.25 \\
\hline 9 & 91L0 & Illyrian oak-hornbeam forests (Erythronio-Carpinion) & 2.20 \\
\hline 10 & 7240 & * Alpine pioneer formations of Caricion bicoloris-atrofuscae & 2.11 \\
\hline 11 & 92A0 & Salix alba and Populus alba galleries & 2.09 \\
\hline 12 & 9160 & $\begin{array}{l}\text { Sub-Atlantic and medio-European oak or oak-hornbeam forests of the } \\
\text { Carpinion betuli }\end{array}$ & 2.03 \\
\hline 13 & 7220 & * Petrifying springs with tufa formation (Cratoneurion) & 2.02 \\
\hline 14 & 7210 & * Calcareous fens with Cladium mariscus and species of the Caricion davallianae & 2.02 \\
\hline 15 & 9260 & Castanea sativa woods & 2.01 \\
\hline 16 & 9510 & * Southern Apennine Abies alba forests & 1.97 \\
\hline 17 & 91AA & ${ }^{*}$ Eastern white oak woods & 1.97 \\
\hline 18 & 6510 & Lowland hay meadows (Alopecurus pratensis, Sanguisorba officinalis) & 1.87 \\
\hline 19 & 91D0 & ${ }^{*}$ Bog woodland & 1.83 \\
\hline
\end{tabular}


Table 3. Habitat types of the Italian Continental biogeographical region ranked with the proposed method $\left({ }^{*}\right.$ highlight priority habitat types sensu Habitats Directive).

\begin{tabular}{|c|c|c|c|}
\hline Rank & Habitat Type Code & Habitat Type Name & Priority Score \\
\hline 1 & 1320 & Spartina swards (Spartinion maritimae) & 3.08 \\
\hline 2 & 1310 & Salicornia and other annuals colonizing mud and sand & 2.57 \\
\hline 3 & 6420 & Mediterranean tall humid grasslands of the Molinio-Holoschoenion & 2.46 \\
\hline 4 & 91B0 & Thermophilous Fraxinus angustifolia woods & 2.44 \\
\hline 5 & 3170 & * Mediterranean temporary ponds & 2.34 \\
\hline 6 & 1420 & Mediterranean and thermo-Atlantic halophilous scrubs (Sarcocornetea fruticosi) & 2.29 \\
\hline 7 & 2230 & Malcolmietalia dune grasslands & 2.25 \\
\hline 8 & 92A0 & Salix alba and Populus alba galleries & 2.23 \\
\hline 9 & 7230 & Alkaline fens & 2.21 \\
\hline 10 & 1410 & Mediterranean salt meadows (Juncetalia maritimi) & 2.21 \\
\hline 11 & 7210 & * Calcareous fens with Cladium mariscus and species of the Caricion davallianae & 2.18 \\
\hline 12 & 6210 & $\begin{array}{l}\text { Semi-natural dry grasslands and scrubland facies on calcareous substrates } \\
\text { (Festuco-Brometalia) }\left({ }^{*} \text { important orchid sites) }\right.\end{array}$ & 2.13 \\
\hline 13 & 2250 & * Coastal dunes with Juniperus spp. & 2.13 \\
\hline 14 & 2260 & Cisto-Lavenduletalia dune sclerophyllous scrubs & 2.06 \\
\hline 15 & 2110 & Embryonic shifting dunes & 1.96 \\
\hline 16 & 9540 & Mediterranean pine forests with endemic Mesogean pines & 1.94 \\
\hline 17 & 3240 & Alpine rivers and their ligneous vegetation with Salix elaeagnos & 1.92 \\
\hline 18 & 2130 & * Fixed coastal dunes with herbaceous vegetation ("grey dunes") & 1.91 \\
\hline 19 & 6520 & Mountain hay meadows & 1.84 \\
\hline 20 & 1210 & Annual vegetation of drift lines & 1.83 \\
\hline 21 & 91AA & * Eastern white oak woods & 1.81 \\
\hline
\end{tabular}

Results were also summarized for groups of habitat types, which enabled a comparison of the priority values assigned to the habitat types of the two biogeographical regions to be made (Figure 3). Bogs and fens are the group with the higher priority in the Alpine biogeographical region, while the coastal and dune habitat types had high overall scores in the Continental biogeographical region. Rocks and screes habitats were of less concern for both regions. Furthermore, forest and grasslands were more of a priority in the Alpine biogeographical region than they were in the Continental biogeographical region.

(a)

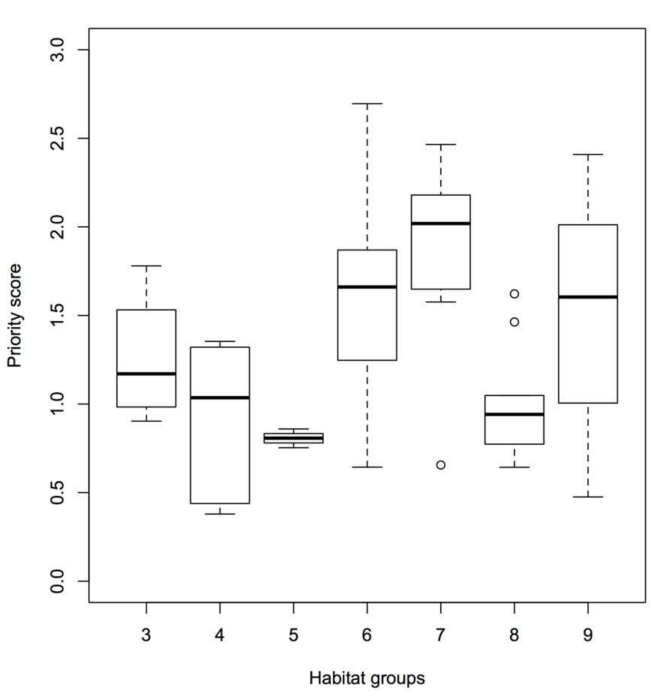

(b)

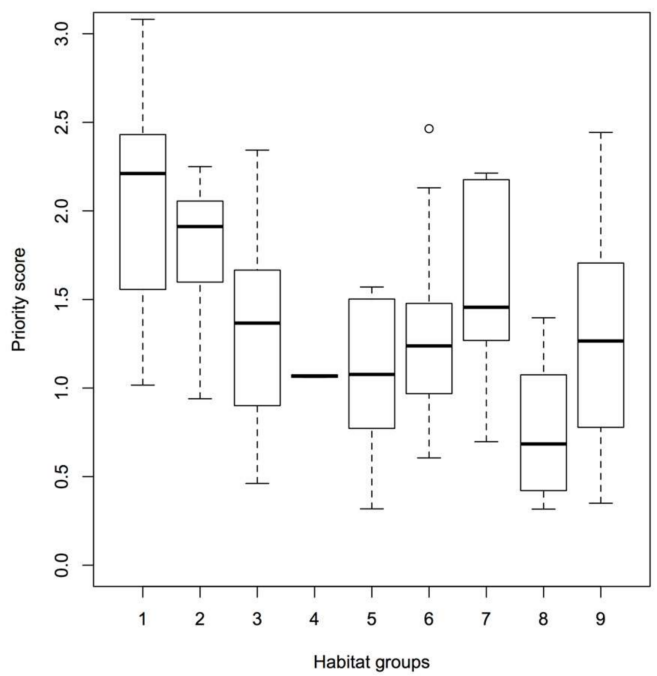

Figure 3. Priority scores of each habitat type groups for the Alpine (a) and Continental (b) biogeographical regions: 1 = coastal, 2 = dune, 3 = water, $4=$ heath, $5=$ scrubland, 6 = grassland, 7 = bogs, $8=$ rock and screes, $9=$ woodlands. 
Ranked habitat types were also plotted against their total score value, with a basically linear trend observed for both biogeographical regions (Figure 4). However, a larger reduction was observed for the highest-ranked habitat types, which highlighted that the higher-ranking habitat types typically had higher values for several criteria, which tended to result in larger differences in the total score. No correlation was found between the different criteria for the two biogeographical regions (Supplementary Material Figures S1 and S2). Given that our results were derived from a unique set of scores for the different parameters, these results may vary if a considerably different set of scores were assigned. Our sensitivity analysis comparing two alternative schemes with the proposed method highlighted a relatively reduced shift in ranking positions (Supplementary Material Figure S3). The alternative rankings shared $79 \%$ and $84 \%$ of priority habitat types with the proposed ranking method. Nevertheless, these analyses confirm that the entity of change in the scoring scheme can effect the final prioritization of habitat types.

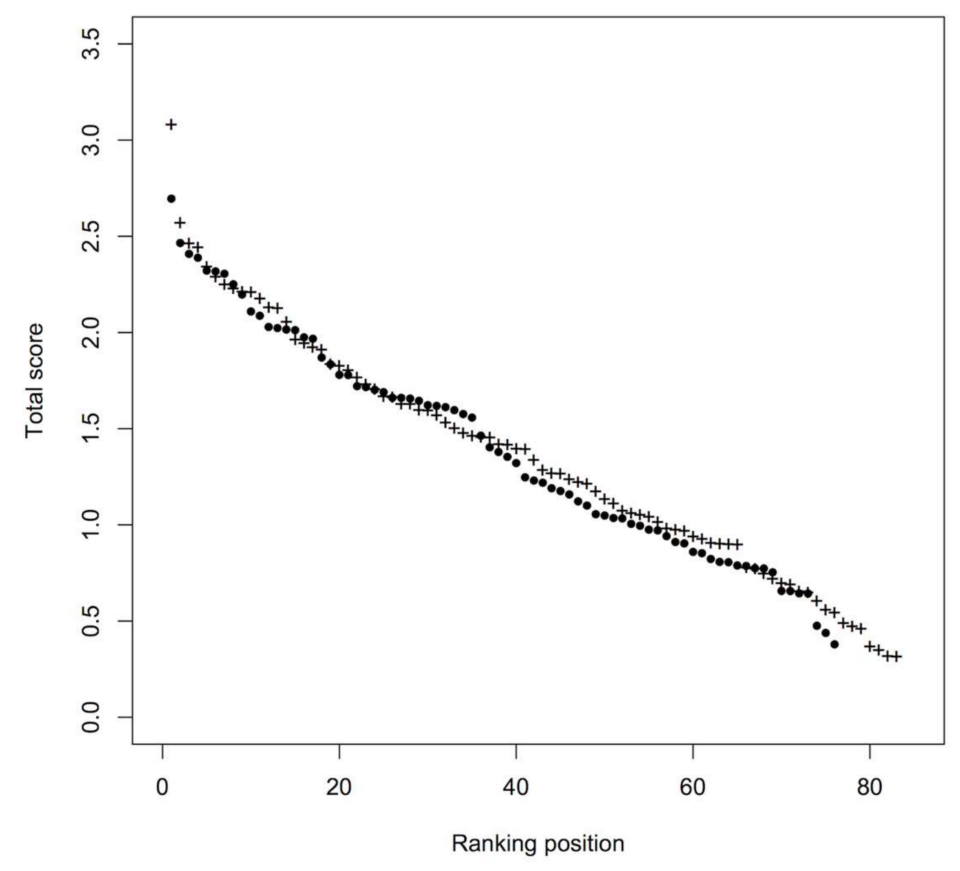

Figure 4. Total score value of habitat types for the Alpine (filled circle symbol) and Continental (plus symbol) biogeographical regions ranked by total score.

Four clusters were formed and identified for the Alpine biogeographical region, and six were formed and identified for the Continental biogeographical region (Figure 5). These groups do not represent single habitat-type categories (e.g., forest habitats), but rather habitat types that may be completely different in ecological characteristics (e.g., habitat type 2260 Cisto-Lavanduletalia dune sclerophyllous scrubs and 91AA *Eastern white oak woods). 
(a)

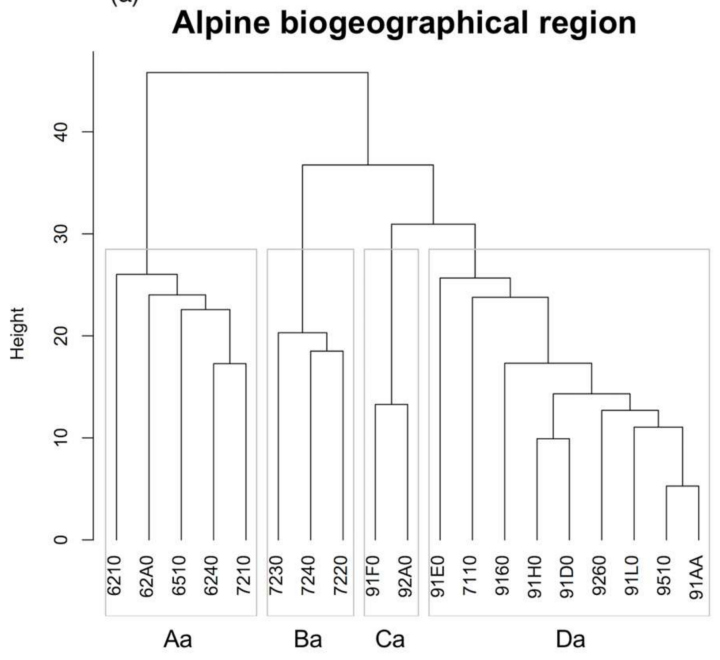

Continental biogeographical region

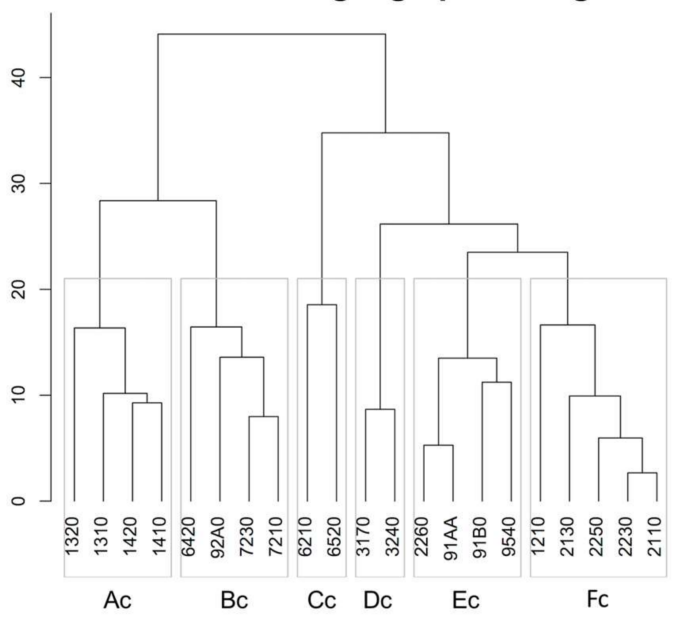

Figure 5. Dendrogram representing the identified groups of habitat types based on their pressure factors for the Alpine, left (a); and Continental, right (b); biogeographical regions (see Table 4 for reference group codes and related pressure factors).

The analysis showed that several factors were shared and are important for the prioritized habitat types of the Alpine and Continental biogeographical regions (Supplementary Material Figure S4 and Table 4). Human-induced changes in hydraulic conditions, agriculture, and natural biotic and abiotic processes were best represented in the clusters (Table 4). However, the most frequent and pressing pressure factor on the prioritized habitat types in both biogeographical regions was "roads and motorways" (code D01.02). The most important factors for the Alpine region were: "other forestry activities" (code B07), "improved access to site" (code D05), "outdoor sports, leisure, and recreational activities" (code G01), and "vegetation succession/biocenotic evolution" (code K02). By contrast, for the Continental region, the most important factor was "urbanization and human habitation" (code E01, see Supplementary Material Figure S4). Among these, some pressure factors were shared by multiple habitat-type groupings; for example, "outdoor sports, leisure, and recreational activities" and "urbanized areas, human habitation" for the Alpine and Continental regions, respectively (Table 4).

Table 4. Pressure factors (and their description taken from http://bd.eionet.europa.eu/activities / Reporting/Article_17/reference_portal; last update 06/05/2015) defining groups identified through cluster analysis with related indicator (IndVal.g) and $p$-values ${ }^{*} p \leq 0.05,{ }^{* *} p \leq 0.01,{ }^{* * *} p \leq 0.001$ ).

\begin{tabular}{ccclcc}
\hline $\begin{array}{c}\text { Alpine } \\
\text { Group }\end{array}$ & $\begin{array}{c}\text { Continental } \\
\text { Group }\end{array}$ & $\begin{array}{c}\text { Pressure } \\
\text { Factors }\end{array}$ & \multicolumn{1}{c}{ Definition } & IndVal.g & $p$ \\
\hline $\mathrm{Cc}$ & $\mathrm{A} 02$ & $\begin{array}{l}\text { Modification of cultivation } \\
\text { practices }\end{array}$ & 1 & $0.01^{* *}$ \\
\hline $\mathrm{Aa}$ & $\mathrm{A} 02.01$ & Agricultural intensification & 0.894 & $0.015^{*}$ \\
\hline $\mathrm{Cc}$ & $\mathrm{A} 04.03$ & $\begin{array}{l}\text { Abandonment of pastoral } \\
\text { systems, lack of grazing }\end{array}$ & 1 & $0.01^{* *}$ \\
\hline $\mathrm{Ac}$ & $\mathrm{A} 07$ & $\begin{array}{l}\text { Use of biocides, hormones } \\
\text { and chemicals }\end{array}$ & 0.846 & $0.026^{*}$ \\
\hline $\mathrm{Fc}$ & $\mathrm{A} 08$ & Fertilization & 0.866 & $0.01^{* *}$ \\
\hline $\mathrm{Ca}+\mathrm{Da}$ & $\mathrm{Ac}+\mathrm{Fc}$ & $\mathrm{A} 08$ & Fertilization & 0.816 & $0.044^{*}$ \\
\hline $\mathrm{Ca}+\mathrm{Da}$ & $\mathrm{B} 02$ & $\begin{array}{l}\text { Forest and plantation } \\
\text { management \& use }\end{array}$ & 0.853 & $0.018^{*}$ \\
\hline
\end{tabular}


Table 4. Cont.

\begin{tabular}{|c|c|c|c|c|c|}
\hline $\begin{array}{l}\text { Alpine } \\
\text { Group }\end{array}$ & $\begin{array}{l}\text { Continental } \\
\text { Group }\end{array}$ & $\begin{array}{l}\text { Pressure } \\
\text { Factors }\end{array}$ & Definition & IndVal.g & $p$ \\
\hline & $\mathrm{Cc}$ & $\mathrm{C} 01$ & Mining and quarrying & 1 & $0.01 * *$ \\
\hline & $\mathrm{Bc}+\mathrm{Cc}+\mathrm{Dc}+\mathrm{Ec}$ & D01.02 & Roads, motorways & 0.894 & $0.013 *$ \\
\hline \multirow[t]{2}{*}{$\mathrm{Ba}+\mathrm{Ca}$} & & D05 & Improved access to site & 0.852 & $0.035^{*}$ \\
\hline & $A c+B c+C c+D c$ & E01 & $\begin{array}{l}\text { Urbanization and human } \\
\text { habitation }\end{array}$ & 0.931 & $0.004^{* *}$ \\
\hline \multirow[t]{2}{*}{$\mathrm{Aa}+\mathrm{Ca}+\mathrm{Da}$} & & G01 & $\begin{array}{l}\text { Outdoor sports, leisure, and } \\
\text { recreational activities }\end{array}$ & 0.901 & $0.033 *$ \\
\hline & $\mathrm{Cc}+\mathrm{Ec}$ & G01.03 & motorized vehicles & 0.816 & $0.05^{*}$ \\
\hline \multirow[t]{3}{*}{$\mathrm{Ca}$} & & G05 & $\begin{array}{l}\text { Other human intrusions and } \\
\text { disturbances }\end{array}$ & 0.802 & $0.025 *$ \\
\hline & Dc & G05.01 & Trampling, overuse & 0.91 & $0.002 * *$ \\
\hline & $\mathrm{Ac}+\mathrm{Bc}+\mathrm{Fc}$ & H01 & Pollution to surface waters & 0.866 & $0.036^{*}$ \\
\hline $\mathrm{Ca}$ & & I01 & Invasive alien species & 0.959 & $0.003 * *$ \\
\hline \multirow[t]{5}{*}{$\mathrm{Ca}$} & & $\mathrm{J} 02$ & $\begin{array}{l}\text { Changes in water bodies } \\
\text { conditions }\end{array}$ & 0.934 & $0.003^{* *}$ \\
\hline & Fc & J.02.01.03 & $\begin{array}{l}\text { Infilling of ditches, dykes, } \\
\text { ponds, pools, marshes, or } \\
\text { pits }\end{array}$ & 0.943 & $0.021 *$ \\
\hline & Ac & J.02.02.02 & $\begin{array}{l}\text { Estuarine and coastal } \\
\text { dredging }\end{array}$ & 1 & $0.002 * *$ \\
\hline & $\mathrm{Ac}+\mathrm{Bc}$ & J02.03.02 & Canalization & 0.935 & $0.002 * *$ \\
\hline & $\mathrm{Cc}+\mathrm{Fc}$ & J02.05 & $\begin{array}{l}\text { Modification of } \\
\text { hydrographic functioning, } \\
\text { general }\end{array}$ & 0.866 & $0.036^{*}$ \\
\hline \multirow[t]{2}{*}{$\mathrm{Ba}$} & & J02.06 & $\begin{array}{l}\text { Water abstractions from } \\
\text { surface waters }\end{array}$ & 0.816 & $0.024 *$ \\
\hline & $\mathrm{Ac}+\mathrm{Bc}$ & J02.07 & $\begin{array}{l}\text { Water abstractions from } \\
\text { groundwater }\end{array}$ & 1 & $0.001 * * *$ \\
\hline $\mathrm{Ca}$ & & J03 & Other changes to ecosystems & 0.926 & $0.003^{* *}$ \\
\hline \multirow[t]{2}{*}{$\mathrm{Aa}+\mathrm{Ca}$} & & K02 & $\begin{array}{l}\text { Vegetation } \\
\text { succession/Biocenotic } \\
\text { evolution }\end{array}$ & 0.851 & $0.039 *$ \\
\hline & Cc & K04.05 & $\begin{array}{l}\text { Damage by herbivores } \\
\text { (including game species) }\end{array}$ & 1 & $0.01 * *$ \\
\hline $\mathrm{Ca}$ & & L08 & Flooding (natural processes) & 0.878 & $0.017 *$ \\
\hline
\end{tabular}

\section{Discussion}

\subsection{Habitat-Type Conservation Priorities and Management for the Case Study Regions}

To assess the utility of the proposed method, a simple comparison can be made with the existing Prioritized Action Frameworks (PAFs) documents (see Article 8 (4) of the Habitats Directive) of the Italian administrative regions falling within the Alpine and Continental biogeographical regions. For example, the PAF for the Veneto region [63,64], which is strongly based on expert opinion, showed congruence with our results (13 habitat types are shared out of the 22 that are indicated at the regional level), highlighting several habitat types among those to be prioritized for conservation management (i.e., 1210, 1410, 2110, 2130, 2230, 2250, 6210, 62A0, 7210, 9160, 91D0, 91E0, 92A0). Similarly, congruence 
on several habitat types can be found from other regional PAFs covering the two biogeographical regions. Therefore, the proposed method could be useful as a tool for preparing PAFs.

Our study revealed the dominant pressure factors for the Alpine and Continental biogeographical regions, which can enable the definition of specific management measures to offset these risks. A number of these pressures are shared between the two biogeographical regions and require urgent actions. The importance of roads and motorways as pressure factors in both regions indicates the need for the specific management and planning of traffic and transport systems. Interestingly, within the overall assessment at the EU level, this pressure category is not among the top-ranked for habitat types, but it is for many species groups [9]. However, specific measures to contrast the pressure derived from roads and motorways can be undertaken, which include: ecologically-sound planning and the appropriate assessment of new roads [38], identifying areas to keep as road-free and low-traffic [65], outlining the spatial extent of roads' impacts for habitats, and reducing effects through restoration and mitigation measures [66]. Changes in agricultural activities due to intensification in some locations and abandonment in others is another important factor in both biogeographical regions, as well as for many habitat types in Europe [67-69]. Indeed, spontaneous succession phenomena and natural processes (e.g., flooding) are important in both areas, and will require active interventions to stabilize habitat types while not overlooking the natural dynamics of the ecosystems.

In addition, for the Alpine region, there are several other conservation management measures that could be encouraged based on the shared pressure factors. Silviculture and forest exploitation must follow near-to-nature approaches that consider habitats' requirements, as it is widely occurring, and the widespread abandonment of forestry activities is to be tackled, at least for certain habitats and areas, in order to enable and preserve habitat heterogeneity. Similarly, outdoors sports, leisure, and recreational activities must be carried out after suitable spatial planning, avoiding direct impacts to habitats and species $[70,71]$. Other recommendations must be given for the Continental biogeographical region. The importance of urbanization and human habitation together with mining and quarrying give an indication that indiscriminate land use changes should be halted and require appropriate spatial planning [72] with related mitigation and restoration actions of the prioritized habitats.

\subsection{A Method for Identifying Habitat-Type Conservation Priorities}

This study considered the conservation needs of natural and semi-natural habitat types and impacting actions, following an approach that takes into account factors that are fundamental in setting conservation priorities [73], which capitalizes on existing methods from previous approaches $[25,28,30,31]$, and utilizes publicly available and officially recognized data. The methodology also utilizes multi-criteria analysis, which is an approach that has been used in previous prioritization of habitat types [33], and has recognized advantages [48]. Other features of the proposed approach, such as the use of a limited number of criteria and not using a complex weighting system, have also been recognized as being advantageous [74]. We use and present score classes to evaluate the different criteria, which is a commonly applied procedure for defining conservation priorities [31,74]. However, the practice of assigning scores to parameters forming the criteria has also been criticized [75], despite its widespread use and perceived utility in previous studies $[25,74,76]$. Indeed, the choice of scores can influence the priority ranking $[76,77]$. Furthermore, our approach does not assign specific weights to these criteria, despite this approach being commonly applied [33]. The assignment of weights is inherently a subjective decision [78], and could be included in our approach based on the stakeholders' preference and experts' knowledge, if required, in order to reflect the relative importance of the different criteria. The criteria and parameters that are suggested in this approach can be viewed as overlapping by definition, even though no correlation was found between the criteria. This issue may be valid for a number of proposed methods [25,32]. Despite this, the relationship between the different criteria must be acknowledged when applying this approach. Overall, the method ensures transparency, repeatability, and consistency. 
The parameters forming the conservation condition are also considered in the "low-hanging fruit" approach [37], among many other methods. However, this approach aims to identify those habitat types for which an improvement in the conservation status could be more easily achieved while taking into account the contribution of the Natura 2000 network, while our approach highlights habitat types that are viewed as having the greatest need of conservation action at the national and biogeographical scale. Urgency of action is also considered in other methods that are focused at the local scale [32]. In our approach, in addition to the cover relevance criteria, the conservation condition also takes into account spatial information such as range and distribution. Spatial information is used among other important information to achieve an appropriate ranking of species and habitat types $[24,25,41,55,74]$, as highlighted with the "national responsibility" approach [79] or by Louette et al. [56]. Indeed, one can integrate the "national responsibility" method with the conservation status [51], and the applicability of this method in Europe has been widely discussed [14]. Furthermore, the consideration of plant species of particular concern within a habitat type also enables the promotion of species conservation and gives a broader view to the conservation approach. Several prioritization approaches consider the presence of threatened species within habitat types as a proxy of habitat conservation value $[28,35,52,53]$.

Management measures can be suggested based on the dominant and shared pressure factors for the habitat types that have conservation priority. A focus on management measures is a current priority aspect in biodiversity conservation [80]. Detailed knowledge regarding the pressures on the biodiversity in the target area is needed to determine appropriate conservation measures [81] that should address the dominant impacts [54,82]. Grouping pressure factors, as applied in our approach, enables a better understanding of the urgency of the measures that can be proposed [32], as well as the identification of the habitat types that will benefit from their application and related area of application. While the Habitats Directive explicitly foresees the management of Natura 2000 sites, the implementation of certain measures outside protected areas is also important for the overall conservation of habitat types and their functional connectivity $[83,84]$.

The proposed method is also adaptable to future changes in data and their availability, as the information gathered within each criterion may be enlarged when other relevant information is obtainable. It should be possible in future applications to consider other relevant parameters within the biodiversity value criteria. For example, some countries have presented a list of animal species among habitat types that are of particular interest, and these lists could be considered if applying the proposed approach to these locations. For the same reason, scoring of this criterion may also take into account whether the habitat type is part of those entered in the "European Red List of Habitats" [85].

Our approach may also be useful outside of the European context, if equivalent information on the four key criteria for habitat-type conservation can be gathered. Even though the approach was tested at the biogeographical level within national administrative boundaries, it would also be possible to either narrow or broaden its geographical application. Indeed, similar data are available at the Natura 2000 site level, but also in some cases in their management plans. Therefore, the application of this method could benefit decision makers at multiple levels, and could be appropriate also for local managers constrained by limited funding availability. At the site level, our method could be integrated with other proposed methods $[39,86]$ to assist in assessments made under Article 6(3) of the Habitats Directive of plans and projects. Furthermore, the approach could be adapted to fulfill regulatory obligations and strategic objectives. In light of the EU 2020 Biodiversity Strategy, the proposed approach would require modifications to the priority ranking of those habitat types requiring minimum action to achieve an increase in their conservation status [37]. Therefore, the conservation condition and pressure factor criteria would be used to identify which habitat types should be considered, and excluding those habitat types that are already in a favorable conservation condition.

Our proposed methodology and subsequent results must also be considered with some caveats. The most important caveat is related to data availability and data quality. Indeed, the availability of biodiversity data is still recognized as a limit for conservation planning [9,87]. While a method for producing data from Article 17 of the Habitats Directive is put forward, it must be emphasized that 
data can derive from many different sources, such as expert knowledge, modeling applications, field surveys, or a mix of these. This can lead to discrepancies and inconsistencies in the methodology between applications and member states [14]. However, it can be assumed that a single member state adopted a consistent approach during its own assessment. Indeed, data acquired from field surveys and derived from modeling can be provided by large scale databases (e.g., forest inventories [88,89]), which can provide reliable assessments of habitat types. Moreover, report information is increasingly being used in biodiversity conservation studies [90-92], which indicates a satisfactory degree of quality. The data from the Article 17 reporting is currently the most extensive database on the conservation status and distribution of habitat types in the EU [14], and in the case of data on Natura 2000 sites, further adjustments to these databases will enable the use of more precise results [34].

Nevertheless, greater scientific attention and inclusion of scientific data is needed to achieve the requirements of Article 17 [44]. Research efforts should focus on those habitat types with a lack of data and information on the parameters forming our method. Indeed, the method has an unavoidable degree of subjectivity in the selection of the parameters and the assignment of their scores. However, the legislative context limits this subjectivity by providing a set of specific features to be included, and this drawback could be further reduced through the inclusion of stakeholders in its application [35].

\section{Conclusions}

In this study, we have presented a replicable approach to identifying conservation priorities for natural and semi-natural habitat types, which integrated data and information derived from the regulatory requirements of the EU. The method combines the prioritization of habitat types based on their conservation condition and value, the actions threatening them, and their areal coverage at the relevant administrative level with the consistent detection of the main pressures requiring management actions for the top-ranked habitat types. By taking a biogeographical perspective framed within national boundaries, the importance of specific biogeographical [93] and administrative characteristics on management decisions can be better taken into account.

Further steps in the development of this approach would involve assessing the importance of expert and stakeholder input on the different criteria, and the comparison of habitat-type rankings between the different current approaches. Furthermore, improvements in data availability and coherence would benefit its application in Europe and in other settings. The structure of this method enables its integration with new data deriving from scientific research, its application at different spatial scales that are important to conservation within Europe (i.e., the EU level, administrative regions, and site), and its application outside of Europe. This approach represents a transparent method for making conservation decisions, and has the potential to help policy makers and managers make better conservation decisions and achieve biodiversity targets.

Supplementary Materials: The following are available online at http:/ /www.mdpi.com/2071-1050/10/4/1189/ s1, Figure S1: Correlation between the scores of CC, CV, PF, CR, and the summed score of CV, PF, and CR for the Alpine biogeographical region; Figure S2: Correlation between the scores of CC, CV, PF, CR, and the summed score of CV, PF, and CR for the Continental biogeographical region; Figure S3: Comparison of habitat type ranking position between the applied priority ranking method ("Priority ranking") and the two alternative examples ("Alternative ranking 1" and ("Alternative ranking 2"). Dots are found on the line if the same ranking position is given to the same habitat type; Figure S4: Number of habitat types (light grey) of conservation priority reported for each pressure factors (Table S4) for the Alpine (top) and Continental (below) biogeographical regions. Codes refer to specific pressures as reported at http://bd.eionet.europa.eu/activities/Reporting/Article_17/reference_portal (last update 06/05/2015), Table S1: Alternative scoring schemes used as example for the sensitivity analysis; Table S2: Habitat type ranking and related total priority score for the Alpine biogeographical region; Table S3: Habitat type ranking and related total priority score for the Continental biogeographical region.

Acknowledgments: We thank Douglas Evans for useful comments and suggestions on an early version of the manuscript. We thank Daniel Hawtree for language revision and useful comments. T. Campagnaro and T. Sitzia were supported by the research project "Forestry of invasive alien species driving changes in plants and soil microbiota communities: the case of black locust (Robinia pseudoacacia L.) in Natura 2000 sites" (CPDA151999/15) funded by the Università degli Studi di Padova. T. Campagnaro was also supported by a doctoral grant funded by the Department of Land, Environment, Agriculture and Forestry of the Università degli Studi di Padova. 
Author Contributions: Thomas Campagnaro conceived and designed the study, analyzed the data, and wrote the paper; Giovanni Trentanovi designed the study and revised the paper; Tommaso Sitzia conceived the study and revised the paper.

Conflicts of Interest: The authors declare no conflict of interest.

\section{References}

1. Geijzendorffer, I.R.; Regan, E.C.; Pereira, H.M.; Brotons, L.; Brummitt, N.; Gavish, Y.; Haase, P.; Martin, C.S.; Mihoub, J.-B.; Secades, C.; et al. Bridging the gap between biodiversity data and policy reporting needs: An essential biodiversity variables perspective. J. Appl. Ecol. 2015, 53, 1341-1350. [CrossRef]

2. Hochkirch, A.; Schmitt, T.; Beninde, J.; Hiery, M.; Kinitz, T.; Kirschey, J.; Matenaar, D.; Rohde, K.; Stoefen, A.; Wagner, N.; et al. Europe needs a new vision for a natura 2000 network. Conserv. Lett. 2013, 6, 462-467. [CrossRef]

3. Tomaselli, V.; Dimopoulos, P.; Marangi, C.; Kallimanis, A.S.; Adamo, M.; Tarantino, C.; Panitsa, M.; Terzi, M.; Veronico, G.; Lovergine, F.; et al. Translating land cover/land use classifications to habitat taxonomies for landscape monitoring: A mediterranean assessment. Landsc. Ecol. 2013, 28, 905-930. [CrossRef]

4. Maiorano, L.; Falcucci, A.; Boitani, L. Gap analysis of terrestrial vertebrates in Italy: Priorities for conservation planning in a human dominated landscape. Biol. Conserv. 2006, 133, 455-473. [CrossRef]

5. Evans, D. The habitats of the European Union Habitats Directive. Biol. Environ. Proc. R. Ir. Acad. 2006, 106B, 167-173. [CrossRef]

6. EEA. Protected Areas in Europe: An Overview; European Environment Agency: Copenhagen, Denmark, 2012.

7. Sundseth, K.; Creed, P. Natura 2000: Protecting Europe's Biodiversity; Office for Official Publications of the European Communities: Luxembourg, 2008.

8. Evans, D.; Arvela, M. Assessment and Reporting Under Article 17 of the Habitats Directive-Explanatory Notes $\mathcal{E}$ Guidelines for the Period 2007-2012. Final Draft, July 2011; European Topic Centre on Biological Diversity: Paris, France, 2011.

9. EEA. State of Nature in the EU. Results from Reporting under the Nature Directives 2007-2012; European Environment Agency: Copenhagen, Denmark, 2015.

10. Fenu, G.; Bacchetta, G.; Giacanelli, V.; Gargano, D.; Montagnani, C.; Orsenigo, S.; Cogoni, D.; Rossi, G.; Conti, F.; Santangelo, A.; et al. Conserving plant diversity in Europe: Outcomes, criticisms and perspectives of the habitats directive application in Italy. Biodivers. Conserv. 2017, 26, 309-328. [CrossRef]

11. Opermanis, O.; MacSharry, B.; Bailly-Maitre, J.; Evans, D.; Sipkova, Z. The role of published information in reviewing conservation objectives for Natura 2000 protected areas in the European Union. Environ. Manag. 2014, 53, 702-712. [CrossRef] [PubMed]

12. Lisón, F.; Altamirano, A.; Field, R.; Jones, G. Conservation on the blink: Deficient technical reports threaten conservation in the Natura 2000 network. Biol. Conserv. 2017, 209, 11-16. [CrossRef]

13. Egoh, B.N.; Paracchini, M.L.; Zulian, G.; Schägner, J.P.; Bidoglio, G. Exploring restoration options for habitats, species and ecosystem services in the European Union. J. Appl. Ecol. 2014, 51, 899-908. [CrossRef]

14. Schmeller, D.S.; Evans, D.; Lin, Y.-P.; Henle, K. The national responsibility approach to setting conservation priorities-Recommendations for its use. J. Nat. Conserv. 2014, 22, 349-357. [CrossRef]

15. Sousa-Silva, R.; Alves, P.; Honrado, J.; Lomba, A. Improving the assessment and reporting on rare and endangered species through species distribution models. Glob. Ecol. Conserv. 2014, 2, 226-237. [CrossRef]

16. Evangelista, A.; Frate, L.; Stinca, A.; Carranza, M.L.; Stanisci, A. Viola-The vegetation database of the central apennines: Structure, current status and usefulness for monitoring Annex I EU habitats (92/43/EEC). Plant Sociol. 2016, 53, 47-58.

17. Gigante, D.; Attorre, F.; Venanzoni, R.; Acosta, A.T.R.; Agrillo, E.; Aleffi, M.; Alessi, N.; Allegrezza, M.; Angelini, P.; Angiolini, C.; et al. A methodological protocol for Annex I habitats monitoring: The contribution of vegetation science. Plant Sociol. 2016, 53, 77-87.

18. EC. Our Life Insurance, Our Natural Capital: An EU Biodiversity Strategy to 2020; European Commission: Brussels, Belgium, 2011.

19. Maiorano, L.; Falcucci, A.; Garton, E.O.; Boitani, L. Contribution of the Natura 2000 network to biodiversity conservation in Italy. Conserv. Biol. 2007, 21, 1433-1444. [CrossRef] [PubMed] 
20. Popescu, V.D.; Rozylowicz, L.; Cogălniceanu, D.; Niculae, I.M.; Cucu, A.L. Moving into protected areas? Setting conservation priorities for Romanian reptiles and amphibians at risk from climate change. PLoS ONE 2013, 8, e79330. [CrossRef] [PubMed]

21. Jantke, K.; Schleupner, C.; Schneider, U.A. Gap analysis of European wetland species: Priority regions for expanding the Natura 2000 network. Biodivers. Conserv. 2011, 20, 581-605. [CrossRef]

22. D'Amen, M.; Bombi, P.; Campanaro, A.; Zapponi, L.; Bologna, M.A.; Mason, F. Protected areas and insect conservation: Questioning the effectiveness of Natura 2000 network for saproxylic beetles in Italy. Anim. Conserv. 2013, 16, 370-378. [CrossRef]

23. Votsi, N.-E.P.; Zomeni, M.S.; Pantis, J.D. Evaluating the effectiveness of Natura 2000 network for wolf conservation: A case-study in Greece. Environ. Manag. 2016, 57, 257-270. [CrossRef] [PubMed]

24. Martín, J.L.; Cardoso, P.; Archavaleta, M.; Borges, P.A.V.; Faria, B.F.; Abreu, C.; Aguilar, A.F.; Carvalho, J.A.; Costa, A.C.; Cunha, R.T.; et al. Using taxonomically unbiased criteria to prioritize resource allocation for oceanic island species conservation. Biodivers. Conserv. 2010, 19, 1659-1682. [CrossRef]

25. Gauthier, P.; Foulon, Y.; Jupille, O.; Thompson, J.D. Quatifying vulnerability to assess priorities for conservation management. Biol. Conserv. 2013, 158, 321-325. [CrossRef]

26. Bani, L.; Massimino, D.; Bottoni, L.; Massa, R. A multiscale method for selecting indicator species and priority conservation areas: A case study for broadleaved forests in Lombardy, Italy. Conserv. Biol. 2006, 20, 512-526. [CrossRef] [PubMed]

27. Schnittler, M.; Günther, K.-F. Central European vascular plants requiring priority conservation measures-An analysis from national red lists and distribution maps. Biodivers. Conserv. 1999, 8, 891-925. [CrossRef]

28. Bragazza, L. Conservation priority of Italian Alpine habitats: A floristic approach based on potential distribution of vascular plant species. Biodivers. Conserv. 2009, 18, 2823-2835. [CrossRef]

29. Angiolini, C.; Viciani, D.; Bonari, G.; Lastrucci, L. Habitat conservation prioritization: A floristic approach applied to a mediterranean wetland network. Plant Biosyst. 2017, 151, 598-612. [CrossRef]

30. Schmeller, D.S.; Maier, A.; Evans, D.; Henle, K. National responsibilities for conserving habitats-A freely scalable method. Nat. Conserv. 2012, 3, 21-44. [CrossRef]

31. Bacchetta, G.; Farris, E.; Pontecorvo, C. A new method to set conservation priorities in biodiversity hotspots. Plant Biosyst. 2012, 146, 37-41. [CrossRef]

32. Velázquez, J.; Tejera, R.; Hernando, A.; Victoria Núñez, M. Environmental diagnosis: Integrating biodiversity conservation in management of Natura 2000 forest spaces. J. Nat. Conserv. 2010, 18, 309-317. [CrossRef]

33. Rossi, G.; Parolo, G.; Ferrarini, A. A rapid and cost-effective tool for managing habitats of the European Natura 2000 network: A case study in the Italian Alps. Biodivers. Conserv. 2009, 18, 1375-1388.

34. Duarte, I.; Rego, F.C.; Casquilho, J.P.; Arsénio, P. A relevance index for the habitat areas of Natura 2000 network based on their rarity and representativeness. Ecol. Indic. 2016, 61, 202-213. [CrossRef]

35. Mikkonen, N.; Moilanen, A. Identification of top priority areas and management landscapes from a national Natura 2000 network. Environ. Sci. Policy 2013, 27, 11-20. [CrossRef]

36. Gauthier, P.; Pons, V.; Letourneau, A.; Klesczewski, M.; Papuga, G.; Thompson, J.D. Combining population monitoring with habitat vulnerability to assess conservation status in populations of rare and endangered plants. J. Nat. Conserv. 2017, 37, 83-95. [CrossRef]

37. Richard, D.; Bailly Maitre, J.; Aronsson, M.; Halada, L. Supporting Elements for the Atlantic Natura 2000 Review Seminar (1st Part: Core Document); European Topic Centre on Biological Diversity: Paris, France, 2016.

38. Sitzia, T.; Campagnaro, T.; Grigolato, S. Ecological risk and accessibility analysis to assess the impact of roads under habitats directive. J. Environ. Plan. Manag. 2016, 59, 2251-2271. [CrossRef]

39. Foresta, M.; Carranza, M.L.; Garfi, V.; Di Febbraro, M.; Marchetti, M.; Loy, A. A systematic conservation planning approach to fire risk management in Natura 2000 sites. J. Environ. Manag. 2016, 181, 574-581. [CrossRef] [PubMed]

40. Tsiafouli, M.A.; Apostolopoulou, E.; Mazaris, A.D.; Kallimanis, A.S.; Drakou, E.G.; Pantis, J.D. Human activities in Natura 2000 sites: A highly diversified conservation network. Environ. Manag. 2013, 51, 1025-1033. [CrossRef] [PubMed]

41. Schatz, B.; Gauthier, P.; Debussche, M.; Thompson, J.D. A decision tool for listing species for protection on different geographic scales and administrative levels. J. Nat. Conserv. 2014, 22, 75-83. [CrossRef] 
42. Maiorano, L.; Amori, G.; Montemaggiori, A.; Rondinini, C.; Santini, L.; Saura, S.; Boitani, L. On how much biodiversity is covered in Europe by national protected areas and by the Natura 2000 network: Insights from terrestrial vertebrates. Conserv. Biol. 2015, 29, 986-995. [CrossRef] [PubMed]

43. Pullin, A.S.; Báldi, A.; Can, O.E.; Dieterich, M.; Kati, V.; Livoreil, B.; Lövei, G.; Mihók, B.; Nevin, O.; Selva, N.; et al. Conservation focus on Europe: Major conservation policy issues that need to be informed by conservation science. Conserv. Biol. 2009, 23, 818-824. [CrossRef] [PubMed]

44. Louette, G.; Adriaens, D.; Paelinckx, D.; Hoffman, M. Implementing the habitats directive: How science can support decision making. J. Nat. Conserv. 2015, 23, 27-34. [CrossRef]

45. Popescu, V.D.; Rozylowicz, L.; Niculae, I.M.; Cucu, A.L.; Hartel, T. Species, habitats, society: An evaluation of research supporting EU's Natura 2000 network. PLoS ONE 2014, 9, e113648. [CrossRef] [PubMed]

46. Campagnaro, T.; Brundu, G.; Sitzia, T. Five major invasive alien tree species in European Union forest habitat types of the Alpine and Continental biogeographical regions. J. Nat. Conserv. 2017. [CrossRef]

47. Genovesi, P.; Angelini, P.; Bianchi, E.; Dupré, E.; Ercole, S.; Giacanelli, V.; Ronchi, F.; Stoch, F. Specie e Habitat di Interesse Comunitario in Italia: Distribuzione, Stato di Conservazione e Trend; ISPRA: Rome, Italy, 2014.

48. Lahdelma, R.; Salminen, P.; Hokkanen, J. Using multicriteria methods in environmental planning and management. Environ. Manag. 2000, 26, 595-605. [CrossRef] [PubMed]

49. Fontana, V.; Radtke, A.; Bossi Fedrigotti, V.; Tappeiner, U.; Tasser, E.; Zerbe, S.; Buchholz, T. Comparing land-use alternatives: Using the ecosystem services concept to define a multi-criteria decision analysis. Ecol. Econ. 2013, 93, 128-136. [CrossRef]

50. Berg, C.; Abdank, A.; Isermann, M.; Jansen, F.; Timmermann, T.; Dengler, J. Red lists and conservation prioritization of plant communities-A methodological framework. Appl. Veg. Sci. 2014, 17, 504-515. [CrossRef]

51. Rossi, E.; Kuitunen, M. Ranking of habitats for the assessment of ecological impact in land use planning. Biol. Conserv. 1996, 77, 227-234. [CrossRef]

52. Zhang, L.; Xu, W.-H.; Ouyang, Z.-Y.; Zhu, C.-Q. Determination of priority nature conservation areas and human disturbances in the Yangtze river basin, China. J. Nat. Conserv. 2014, 22, 326-336. [CrossRef]

53. Benavent-González, A.; Lumbreras, A.; Molina, J.A. Plant communities as a tool for setting priorities in biodiversity conservation: A novel approach to Iberian aquatic vegetation. Biodivers. Conserv. 2014, 23, 2135-2154. [CrossRef]

54. Louette, G.; Adriaens, D.; Adriaens, P.; Anselin, A.; Devos, K.; Sannen, K.; Van Landuyt, W.; Paelinckx, D.; Hoffman, M. Bridging the gap between the Natura 2000 regional conservation status and local conservation objectives. J. Nat. Conserv. 2011, 19, 224-235. [CrossRef]

55. Legendre, P.; Legendre, L. Numerical Ecology; Elsevier Science: Amsterdam, The Netherlands, 1998 ; Volume 2.

56. Schmeller, D.S.; Bauch, B.; Gruber, B.; Juškaitis, R.; Budrys, E.; Babij, V.; Sammul, M.; Varga, Z.; Henle, K. Determination of conservation priorities in regions with multiple political juristictions. Biodivers. Conserv. 2008, 17, 3623. [CrossRef]

57. Bunce, R.G.H.; Bogers, M.M.B.; Evans, D.; Halada, L.; Jongman, R.H.G.; Mucher, C.A.; Bauch, B.; de Blust, G.; Parr, T.W.; Olsvig-Whittaker, L. The significance of habitats as indicators of biodiversity and their links to species. Ecol. Indic. 2013, 33, 19-25. [CrossRef]

58. Salafsky, N.; Salzer, D.; Stattersfield, A.J.; Hilton-Taylor, C.; Neugarten, R.; Butchart, S.H.M.; Collen, B.; Cox, N.; Master, L.L.; O'Connor, S.; et al. A standard lexicon for biodiversity conservation: Unified classification of threats and actions. Conserv. Biol. 2008, 22, 897-911. [CrossRef] [PubMed]

59. R Development Core Team. R: A Language and Environment for Statistical Computing; R Foundation for Statistical Computing: Vienna, Austria, 2015.

60. Fabbris, L. Statistica Multivariata. Analisi Esplorativa Dei Dati; McGraw-Hill Libri Italia: Milano, Italy, 1997.

61. Dufrêne, M.; Legendre, P. Species assemblages and indicator species: The need for a flexible asymmetrical approach. Ecol. Monogr. 1997, 67, 345-366. [CrossRef]

62. De Cáceres, M.; Legendre, P.; Moretti, M. Improving indicator species analysis by combining groups of sites. Oikos 2010, 119, 1674-1684. [CrossRef]

63. Veneto Region. Programma di sviluppo rurale per il Veneto 2007-2013. Dgr n. 746 del 15 marzo 2010 e s.M.I., misura 511-Assistenza tecnica. Approvazione del documento "Prioritised Action Framework-PAF" per le aree nella rete Natura 2000 relativamente al periodo di programmazione comunitaria 2014-2020. In Deliberazione Della Giunta Regionale n. 683; Bollettino Ufficiale della Regione del Veneto: Venice, Italy, 2015. 
64. Causin, L.; Campagnaro, T.; Trentanovi, G.; Cassol, M.; Lasen, C.; Maso, D.; Cavalli, R.; Sitzia, T. Metodo e sintesi dei risultati ottenuti nella redazione del PAF "Prioritised Action Framework" per la conservazione della biodiversità nella rete Natura 2000 del Veneto. In $7^{\circ}$ Convegno Faunisti Veneti; Bonato, L., Trabucco, R., Bon, M., Eds.; Bollettino del Museo di Storia Naturale di Venezia: Verona, Italy, 2016; Volume 66, pp. 9-19.

65. Selva, N.; Kreft, S.; Kati, V.; Schluck, M.; Jonsson, B.-G.; Mihok, B.; Okarma, H.; Ibisch, P.L. Roadless and low-traffic areas as conservation targets in Europe. Environ. Manag. 2011, 48, 865-877. [CrossRef] [PubMed]

66. Ottburg, F.; Blank, M. Solutions to the impacts of roads and other barriers on fish and fish habitat. In Handbook of Road Ecology; van der Ree, R., Smith, D.J., Grilo, C., Eds.; John Wiley \& Sons Ltd: West Sussex, UK, 2015; pp. 364-373.

67. Ostermann, O.P. The need for management of nature conservation sites designated under Natura 2000. J. Appl. Ecol. 1998, 35, 968-973. [CrossRef]

68. Halada, L.; Evans, D.; Romão, C.; Petersen, J.-E. Which habitats of European importance depend on agricultural practices? Biodivers. Conserv. 2011, 20, 2365-2378. [CrossRef]

69. Campagnaro, T.; Frate, L.; Carranza, M.L.; Sitzia, T. Multi-scale analysis of alpine landscapes with different intensities of abandonment reveals similar spatial pattern changes: Implications for habitat conservation. Ecol. Indic. 2017, 74, 147-159. [CrossRef]

70. Muñoz-Santos, M.; Benayas, J. A proposed methodology to assess the quality of public use management in protected areas. Environ. Manag. 2012, 50, 106-122. [CrossRef] [PubMed]

71. Sitzia, T.; Rizzi, A.; Cattaneo, D.; Semenzato, P. Designing recreational trails in a forest dune habitat using least-cost path analysis at the resolution of visitor sight distance. Urban For. Urban Green. 2014, 13, 861-868. [CrossRef]

72. Falcucci, A.; Maiorano, L.; Boitani, L. Changes in land-use/land-cover patterns in Italy and their implications for biodiversity conservation. Landsc. Ecol. 2007, 22, 617-631. [CrossRef]

73. Stroud, J.T.; Rehm, E.; Ladd, M.; Olivas, P.; Feeley, K.J. Is conservation research money being spent wisely? Changing trends in conservation research priorities. J. Nat. Conserv. 2014, 22, 471-473. [CrossRef]

74. Gauthier, P.; Debussche, M.; Thompson, J.D. Regional priority setting for rare species based on a method combining three criteria. Biol. Conserv. 2010, 143, 1501-1509. [CrossRef]

75. Ribeiro, B.R.; Brum, F.T.; Pressey, R.L.; Loyola, R. Scoring methods do not provide reliable conservation priorities for marine biodiversity protection. Biol. Conserv. 2017. [CrossRef]

76. Geneletti, D.; van Duren, I. Protected area zoning for conservation and use: A combination of spatial multicriteria and multiobjective evaluation. Landsc. Urban Plan. 2008, 85, 97-110. [CrossRef]

77. Favretto, N.; Stringer, L.C.; Dougill, A.J.; Dallimer, M.; Perkins, J.S.; Reed, M.S.; Atlhopheng, J.R.; Mulale, K. Multi-criteria decision analysis to identify dryland ecosystem service trade-offs under different rangeland land uses. Ecosyst. Serv. 2016, 17, 142-151. [CrossRef]

78. Pearce, J.L.; Kirk, D.A.; Lane, C.P.; Mahr, M.H.; Walmsley, J.; Casey, D.; Muir, J.E.; Hannon, S.; Hansen, A.; Jones, K. Prioritizing avian conservation areas for the yellowstone to yukon region of North America. Biol. Conserv. 2008, 141, 908-924. [CrossRef]

79. Schmeller, D.S.; Gruber, B.; Bauch, B.; Lanno, K.; Budrys, E.; Babij, V.; Juškaitis, R.; Sammul, M.; Varga, Z.; Henle, K. Determination of national conservation responsabilities for species conservation in regions with multiple political juristictions. Biodivers. Conserv. 2008, 17, 3607. [CrossRef]

80. Watson, J.E.M.; Dudley, N.; Segan, D.B.; Hockings, M. The performance and potential of protected areas. Nature 2014, 515, 67-73. [CrossRef] [PubMed]

81. Wilson, K.; Pressey, R.L.; Newton, A.; Burgman, M.; Possingham, H.; Weston, C. Measuring and incorporating vulnerability into conservation planning. Environ. Manag. 2005, 35, 527-543. [CrossRef] [PubMed]

82. Fenu, G.; Fois, M.; Cogoni, D.; Porceddu, M.; Pinna, M.S.; Lombraña, A.C.; Nebot, A.; Sulis, E.; Picciau, R.; Santo, A.; et al. The aichi biodiversity target 12 at regional level: An achievable goal? Biodiversity 2015, 16, 120-135. [CrossRef]

83. Orlikowska, E.H.; Roberge, J.-M.; Blicharska, M.; Mikusiński, G. Gaps in ecological research on the world's largest internationally coordinated network of protected areas: A review of Natura 2000. Biol. Conserv. 2016, 200, 216-227. [CrossRef]

84. Opermanis, O.; MacSharry, B.; Evans, D.; Sipkova, Z. Is the connectivity of the Natura 2000 network better across internal or external administrative borders? Biol. Conserv. 2013, 166, 170-174. [CrossRef] 
85. Janssen, J.A.M.; Rodwell, J.S.; García Criado, M.; Gubbay, S.; Haynes, T.; Nieto, A.; Sanders, N.; Landucci, F.; Loidi, J.; Ssymank, A.; et al. European Red List of Habitats. Part. 2. Terrestrial and Freshwater Habitats; Publications Office of the European Union: Luxembourg, 2016.

86. Caniani, D.; Labella, A.; Lioi, D.S.; Mancini, I.M.; Masi, S. Habitat ecological integrity and environmental impact assessment of anthropic activities: A gis-based fuzzy logic model for sites of high biodiversity conservation interest. Ecol. Indic. 2016, 67, 238-249. [CrossRef]

87. Gaston, K.J.; Jackson, S.F.; Nagy, A.; Cantú-Salazar, L.; Johnson, M. Protected areas in Europe. Ann. N. Y. Acad. Sci. 2008, 1134, 97-119. [CrossRef] [PubMed]

88. Winter, S.; Chirici, G.; McRoberts, R.E.; Hauk, E.; Tomppo, E. Possibilities for harmonizing national forest inventory data for use in forest biodiversity assessments. Forestry 2008, 81, 33-44. [CrossRef]

89. Kovač, M.; Kutnar, L.; Hladnik, D. Assessing biodiversity and conservation status of the Natura 2000 forest habitat types: Tools for designated forestlands stewardship. For. Ecol. Manag. 2016, 359, 256-267. [CrossRef]

90. Mazaris, A.D.; Papanikolaou, A.D.; Barbet-Massin, M.; Kallimanis, A.S.; Jiguet, F.; Schmeller, D.S.; Pantis, J.D. Evaluating the connectivity of a protected areas' network under the prism of global change: The efficiency of the European Natura 2000 network for four birds of prey. PLoS ONE 2013, 8, e59640. [CrossRef] [PubMed]

91. Gigante, D.; Foggi, B.; Venanzoni, R.; Viciani, D.; Buffa, G. Habitats on the grid: The spatial dimension does matter for red-listing. J. Nat. Conserv. 2016, 32, 1-9. [CrossRef]

92. Trentanovi, G.; Campagnaro, T.; Rizzi, A.; Sitzia, T. Synergies of planning for forests and planning for Natura 2000: Evidences and prospects from Northern Italy. J. Nat. Conserv. 2017. [CrossRef]

93. Kukkala, A.S.; Arponen, A.; Maiorano, L.; Moilanen, A.; Thuiller, W.; Toivonen, T.; Zupan, L.; Brotons, L.; Cabeza, M. Matches and mismatches between national and EU-wide priorities: Examining the Natura 2000 network in vertebrate species conservation. Biol. Conserv. 2016, 198, 193-201. [CrossRef]

(C) 2018 by the authors. Licensee MDPI, Basel, Switzerland. This article is an open access article distributed under the terms and conditions of the Creative Commons Attribution (CC BY) license (http:/ / creativecommons.org/licenses/by/4.0/). 